\title{
1. Common concern and the legitimacy of the WTO in dealing with climate change
}

Thomas Cottier and Tetyana Payosova*

\section{INTRODUCTION}

Climate change, as a matter of international relations, is dealt with under the United Nations Framework Convention on Climate Change (UNFCCC) and related instruments. It is also addressed in bilateral or regional agreements specifically targeting the issue, but it has not been at the heart of international trade regulation. Neither the World Trade Organization (WTO) nor preferential trade agreements or trade and investment agreements specifically address the problem. Yet most of the policies addressing climate change use trade-related policies and tools. Inevitably, issues of compatibility with WTO law arise. Moreover, questions arise as to what extent the existing framework of trade regulation is responsive to the problem, or rather remains a stumbling block to addressing climate change mitigation and adaption.

We argue in this chapter that climate change, as well as other environmental issues, not only inevitably touch upon WTO law, but that international trade regulation has to make a proactive contribution to the advancement of climate change mitigation and adaption and the attainment of abatement goals. Supporting and achieving these goals will in turn enhance the output legitimacy of WTO law ${ }^{1}$ and its acceptance as one of the main pillars of global governance. The UNFCCC recognizes climate change as a common concern of humankind. We argue that common concern provides the foundation for an emerging principle, which is equally suitable to inform the contours of trade regulation responsive to the immense challenge of climate change.

Climate change has several unique features that differentiate it from other environmental problems that humanity has previously faced. Firstly, climate change is a truly global problem, characterized by many uncertainties on the one hand and potentially irreversible consequences on the other. Its global nature creates a need for collective, global action. However, the multiplicity of decision-makers and the weakness of international institutions operating under consensus rules limit the scope of the

* Contact: thomas.cottier@iew.unibe.ch and tetyana.payosova@iew.unibe.ch. The chapter is largely based upon work done within WP 5 of the NCCR International Trade Regulation, and published in Thomas Cottier, Philipp Aerni, Baris Karapinar, Sofya Matteotti, Joelle de Sépibus and Anirudh Shingal, 'The Principle of Common Concern and Climate Change' (2014) 52 Archiv des Völkerrechts 293. We are grateful to colleagues in the WP 5 for lively discussions and Susan Kaplan for skillfully editing the paper.

1 See T Cottier, 'The legitimacy of WTO law', in: Y Linda (ed.), The Law and Economics of Globalisation. New Challenges for a World in Flux (Edward Elgar 2009), at 11-48. 
necessary collective action. Policy responses chosen by decision-makers are often difficult to agree upon at the international level, due to unequal intensity of domestic greenhouse gas (GHG) emissions and the heterogeneous consequences of such emissions around the world. ${ }^{2}$ This leads to a failure of collective action. Furthermore, the climate change problem is a long-term challenge, which cannot be solved instantly; whatever actions are taken (or not taken), they result in intergenerational transfers of effects of chosen policy responses. As societies have to adapt their habits to such policy responses (e.g. additional taxes on 'grey' energy, energy efficiency requirements), radical policy decisions often face strong opposition from society and industries. Thus, they are often postponed, depending on a given political setting.

Such difficulties imply that dealing with climate change needs much deeper international cooperation than other environmental problems with local or regional impact. It is, for such reasons, characterized as a common concern of humankind. The notion, at this stage, poses more questions than it resolves. The chapter seeks to clarify its contours as it relates to established principles of international law. We touch upon the relationship to public goods and to the well-established principle of permanent sovereignty over natural resources and the corresponding obligation not to cause transboundary environmental harm, the common heritage of mankind, and the principle of equity. We then turn to the potential effects of an emerging principle of common concern in the field of climate change mitigation and adaptation and the corresponding implications of, and on, WTO law.

\section{THE COMMON CONCERN OF CLIMATE CHANGE}

\subsection{Climate as a Global Public Good?}

It is well established that the climate of the Earth depends, inter alia, on emissions of GHGs in each and every part of the world. ${ }^{3}$ The effects of emissions are inherently extraterritorial and global. They cannot be confined to particular territories. It is thus often suggested that the starting point for a discussion on common concern is to address whether the climate itself constitutes a global public good. ${ }^{4}$

The ordinary meaning of the economic term 'public good' suggests that it is 'a commodity or a service that is provided without profit to all members of a society,

2 IPCC Reports, 'Climate Change 2001. Working Group III: Mitigation', Section 10. Available at: http://www.ipcc.ch/ipccreports/tar/wg3/index.php?idp=0 accessed 28 July 2016.

3 UNEP/WTO, Trade and Climate Change. A Report by the United Nations Environment Programme and the World Trade Organization (2009), at 2-16.

4 For instance, it has been suggested that ' $[\mathrm{t}]$ raditional environmental air-pollution problems have been amenable to local solutions. [...] With climate change it is the emissions of all sources in all nations that determine the concentration of greenhouse gases (GHGs) in the atmosphere. As a consequence, the climate change problem is inherently a public goods problem. That is, the climate that everyone enjoys is the product of everyone's behavior'. See IPCC Reports, Climate Change 2001, Working Group III: Mitigation. Available at: http:// www.ipcc.ch/ipccreports/tar/wg3/index.php?idp=0 accessed 28 July 2016, Section 10. 
either by the government or by a private individual or organization'.5 Although Adam Smith had already referred to defence or institutions of justice as examples of public goods, Paul Samuelson was the first to systematically develop the theory of public goods. ${ }^{6}$ Samuelson called them 'collective consumption goods', which he defined as '[goods] which all enjoy in common in the sense that each individual's consumption of such a good leads to no subtractions from any other individual's consumption of that good'. All public goods include common or collective benefits provided by governments (justice, police, healthcare). ${ }^{7}$ This definition reflects the first key characteristic of a public good, namely that it is non-rivalrous and non-exclusive. In this sense, consumption of the public, common good by one person will not lead to a reduction of its availability for actual or potential consumptions by others.

While the original theoretical concept of public goods does not differentiate between types of public goods based on their geographical scope (local, regional, global), such distinctions are possible. ${ }^{8}$ Public goods that can be characterized as 'global' can be only those goods whose beneficial effects cross borders, generations and reach various population groups around the globe, for example, knowledge. Such global public goods cannot be created by a single individual and require a common effort at the international level. ${ }^{9}$ They need to be addressed on an appropriate regulatory level within multilevel governance. ${ }^{10}$ Global public goods regularly call for framing on the global level. States cooperating in international organizations play an important part in creating global public goods and in regulating and managing them. ${ }^{11}$ The global trading system, embodied in the rules of the WTO, is a prime example of a global public good. It depends upon an appropriate framework and instruments. If these fail, the global public good cannot be produced or maintained. ${ }^{12}$

According to these definitions is climate a global public good? In a narrow sense, climate amounts to 'average weather', i.e. 'a statistical description in terms of the mean and variability of relevant quantities (temperature, precipitation and wind) over a period ranging from months to thousands or millions of years'. ${ }^{13}$ Climate in a wider sense is

5 Oxford Dictionaries Online. Available at: http://www.oxforddictionaries.com accessed 28 July 2016.

6 PA Samuelson, 'The Pure Theory of Public Expenditure', (1954) 36(4) The Review of Economics and Statistics 387, at 387-9.

7 M Olson, The Logic of Collective Action (Harvard University Press 1971), at 14; H Gravelle and R Rees, Microeconomics, 3rd ed. (FT/Prentice Hall 2004), 326.

8 I Kaul, I Grunberg and M Stern (eds), Global Public Goods: International Cooperation in the 21st Century (Oxford University Press 1999).

9 Kaul, Grunberg and Stern, above note 8, at xxi.

10 T Cottier, P Aerni, B Karapinar, S Matteotti, J de Sépibus, A Shingal, 'The Principle of Common Concern and Climate Change', (2014) 52 Archiv des Völkerrechts 293; see also: EU Petersmann (ed.), 'Multilevel Governance of Interdependent Public Goods: Theories, Rules and Institutions for the Central Policy Challenge in the 21st Century', (2012) EUI Working Papers RSCAS 2012/13.

11 Olson, above note 7, at 15-6.

12 The international climate change regime with the IPCC and the framework established under the UNFCC and Kyoto Protocol illustrate this case in practice.

13 IPCC, Glossary. Available at: http://www.ipcc.ch/ipccreports/tar/wg1/518.htm accessed 28 July 2016. 


\section{Research handbook on climate change and trade law}

the state of the climatic system. As a status, it can hardly qualify as a global public good, ${ }^{14}$ whereas sustainable climate management can be so characterized. In the absence of a system of sustainable climate management, a global common concern emerges instead of common good. Consequently, common concerns have to be addressed by means of appropriate responses at the appropriate layers of governance in order to create a global public good.

\subsection{The Collective Action Problem of Mitigating Climate Change}

Climate change is a vivid example of a collective action problem that has led to a common concern instead of a common good. ${ }^{15}$ The organization that is responsible for the creation of public goods needs appropriate incentives, encouragement and sanctions to ensure participation of the actors that make the creation of public goods possible and render the activities of that organization legitimate. So far, the international climate change framework has not been successful either in creating powerful incentives for states to fully engage and commit, or in creating efficient sanctions for non-compliance with its rules. ${ }^{16}$

The collective action problem generally refers to a situation where all actors involved would benefit from joint efforts and collective participation, but instead pursue individual targets and act in a non-concerted manner, leading to a worse result for all actors alike. The apogee of collective action failure is the 'tragedy of the commons'. All participants are acting solely in their own interests while depleting the shared finite resources. ${ }^{17}$ In the process of globalization, and despite it, diverging domestic interests often prevail in the absence of appropriate and efficient international organizations to

14 Cottier, Aerni, Karapinar, Matteotti, de Sépibus, Shingal, above note 10.

15 DC Esty and ALI Moffa, 'Why Climate Change Collective Action has Failed and What Needs to Be Done Within and Without the Trade Regime', (2012) 15(3) Journal of International Economic Law 777; PG Harris, 'Collective Action on Climate Change: The Logic of Regime Failure', (2007) 47 Natural Resources Journal 195; L Schenk, 'Climate Change "Crisis"Struggling for Worldwide Collective Action', (2008) 19(3) Colorado Journal on International Environmental Law and Policy 319; see also I Otker-Robe, 'Global Risks and Collective Action Failures: What Can the International Community Do?', IMF Working Papers 14/195.

16 In general, on climate change negotiations, D Bodansky, 'The United Nations Framework Convention on Climate Change: A Commentary', (2013) 18 Yale Journal of International Law 451. The post-Kyoto international climate change agreement was adopted by 195 countries at the UNFCCC COP21 in Paris in December 2015. Whereas it constitutes a major achievement in setting the global action plan to tackle climate change by the world community, including the major emitters, the Paris Agreement still does not impose mandatory emission reduction targets and neither does it foresee sanctions for non-compliance. See: UNFCCC, Paris Agreement 2015. FCCC/CP/2015/L.9/Rev1.

17 The theory of the tragedy of commons was developed by the biologist Garrett Hardin, see: G Hardin, 'The Tragedy of the Commons', (1968) 162 Science 1243. 
resolve the 'collective action problem' and to produce global public goods. ${ }^{18}$ In this sense, all common concerns are a result of collective action failures.

Many uncertainties appertain to climate change, although the broad picture of possible consequences of human-induced climate change is evident. The cost-benefit analysis (CBA) of participating in a climate change regime does not provide a clear picture with respect to the costs of the problem and the potential benefits of its solution through the creation of a global public good. ${ }^{19}$ The uncertainties are magnified not only by potentially geographically distant effects of non-cooperative action (the uneven distribution of effects), but also by the fact that the effects are mainly distant in time. Key players are not necessarily the members of the group that are most vulnerable to the negative impact of climate change. Thus, the collective action problem can be broadly described, especially in the case of climate change, as a gap between knowledge and action.

\subsection{Origins of Common Concern}

Environmental problems often cross national boundaries and thus go beyond the borders of single national jurisdictions. The environment, which does not belong to any individual state and thus represents an interest for multiple states, can no longer be perceived purely from a perspective of state sovereignty. ${ }^{20}$ Long before the debate on climate change emerged, the notion of 'common concern' arose in the context of dealing with common problems relating to overlapping jurisdictions and shared resources. ${ }^{21}$ Since 1949 tuna and other fish have been considered to be 'of common concern' to a number of states. ${ }^{22}$ With respect to the atmosphere, Pardo was the first to suggest that it should be characterized as a common heritage of humankind. ${ }^{23}$ This idea was later taken up by the United Nations in the preparation of its Resolution on climate change. ${ }^{24}$ However, the final version of the 1988 UN General Assembly Resolution 43/53 titled 'Protection of Global Climate for Present and Future Generations of Mankind' referred to climate change as a 'common concern of mankind', instead of a

18 See E Brousseau, T Dedeurwaerdere, P-A Jouvet and M Willinger (eds), Global Environmental Commons: Analytical and Political Challenges in Building Governance Mechanisms (Oxford University Press 2012); I Kaul, 'Global Public Goods: Explaining their Underprovision', (2012) 15 Journal of International Economic Law 729.

19 See N Stern, The Economics of Climate Change: The Stern Review (Cambridge University Press 2007).

20 T Cottier and S Matteotti-Berkutova, 'International Environmental Law and the Evolving Concept of "Common Concern of Mankind", in T Cottier, O Nartova and SZ Bigdeli (eds), International Trade Regulation and the Mitigation of Climate Change, 11th World Trade Forum (Cambridge University Press 2009), at 21.

21 E Köhler, 'Common Concern of Mankind: Die historischen Entwicklungen des Konzepts und seine inhaltliche Bedeutung', Master Thesis, University of Bern (2012) (on file with authors).

22 Inter-American Tropical Tuna Convention, 31 May 1949, 80 UNTS 3, 3 (entered into force 1950).

23 A Pardo, 'Whose is the Bed of the Sea?', (1968) 62 Proceedings of the American Society International Law 216, at 225.

24 UN Doc. A/43/241 (1988). 


\section{Research handbook on climate change and trade law}

'common heritage', as 'climate is an essential condition which sustains life on earth'. ${ }^{25}$ This was the first shift from common heritage to common concern with respect to climate change.

Thereafter, the concept of 'common concern' was explicitly referred to in several international treaties. First, the UNFCCC stated that the "change in the earth's climate and its adverse effects are a common concern of humankind' ${ }^{26}$ Consequently the 'common concern' was used in the context of biodiversity, ${ }^{27}$ depletion of the ozone layer and environmental pollution due to disposal of hazardous wastes, ${ }^{28}$ plant genetic resources $^{29}$ and cultural heritage. ${ }^{30}$ While the notion of common concern is most often used in a context of environmental law, it is clearly not limited to this field. Recently, it has been suggested that human rights ${ }^{31}$ and exchange rate policies ${ }^{32}$ also amount to contemporary common concerns. Finally, it should be noted that common concern is not static. ${ }^{33}$ New common concerns may arise as new unresolved collective action problems are identified and society develops and changes over time. While the material scope of 'common concern' seems to expand over time, it remains unclear whether it

25 Protection of Global Climate for Present and Future Generations of Mankind, G.A. Res. 43/53, U.N. Doc. A/RES/43/53 (Dec. 6, 1988). Available at: http://www.un.org/documents/ga/ res/43/a43r053.htm accessed 28 July 2016.

26 United Nations Framework Convention on Climate Change, 9 May 1992, 31 ILM 849-51.

27 Convention on Biological Diversity, 5 June 1992, 31 ILM 818-22; see e.g. A Jaeckel, 'Intellectual Property Rights and the Conservation of Plant Biodiversity as a Common Concern of Humankind', (2013) 2(1) Transnational Environmental Law 167.

28 See: Montreal Protocol on Substances that Deplete the Ozone Layer, 26 ILM 1550 (1987); Basel Convention on the Control of Transboundary Movements of Hazardous Wastes and their Disposal, 28 ILM 657 (1989); Convention on International Trade in Endangered Species of Wild Fauna and Flora, 12 ILM 1085 (1973). See also: T Koivurova, Introduction to International Environmental Law (Routledge 2013), at 190-3; J Werksman, 'Consolidating Governance of the Global Commons: Insights from the Global Environment Facility' (1995) 6(1) Yearbook of International Environmental Law 27, at 41.

29 International Treaty on Plant Genetic Resources for Food and Agriculture (ITPGRFA), FAO, 3 November 2001. Available at: ftp://ftp.fao.org/docrep/fao/011/i0510e/i0510e.pdfftp:// ftp.fao.org/docrep/fao/011/i0510e/i0510e.pdf accessed 28 July 2016; see e.g. A Smagadi, 'Analysis of the Objectives of the Convention on Biological Diversity: Their Interrelation and Implementation Guidance for Access and Benefit Sharing', (2006) 31 Columbia Journal of Environmental Law 243, at 246-50.

30 Convention for the Safeguarding of the Intangible Cultural Heritage adopted 17 October 2003. Available at: http://portal.unesco.org/en/ev.php-URL_ID=17716\&URL_DO=DO_TOPIC \&URL_SECTION=201.html accessed 28 July 2016; see also JP Fishman, 'Locating the International Interest in Intranational Cultural Property Disputes', (2010) 35 Yale Journal of International Law 347, at 357-68.

31 C Beitz, 'Human Rights as a Common Concern', (2001) 95(2) American Political Science Review 269; see also L Horn, 'The Implications of the Concept of Common Concern of a Human Kind on a Human Right to a Healthy Environment', (2004) 1 Macquarie Journal of International and Comparative Environmental Law 233.

32 Z Kontolemis, 'Exchange Rates Are a Matter of Common Concern: Policies in the Run-up to the Euro?', (2003) Directorate General Economic and Monetary Affairs Papers 191.

33 R Leal-Arcas, Climate Change and International Trade (Edward Elgar 2013), at 91. 
goes beyond the concept of common interests established in the law of the sea in relation to the high seas. ${ }^{34}$

\subsection{Enhanced International Cooperation and Integration of Efforts}

The normative value of 'common concern' is to a large extent framed by the respective obligations pertaining to it. The need for enhanced cooperation to deal with climate change (but also with other common concerns) is evident both from the nature of the problem and from the magnitude of its possible consequences. The UNFCCC explicitly calls for 'the widest possible cooperation by all countries and their participation in an effective and appropriate international response', but at the same time reaffirms the principle of sovereignty within the international cooperation itself. ${ }^{35}$ The most recent Resolution of the UN General Assembly on the 2030 Agenda for Sustainable Development calls all countries to cooperate for the achievement of 17 post-2015 Sustainable Development Goals, including combating climate change. ${ }^{36}$

The need for enhanced cooperation is also reflected in the development of an obligation not to cause transboundary harm, which through international jurisprudence was extended to an obligation to engage in 'meaningful negotiations'. ${ }^{37}$ In the jurisprudence of the International Court of Justice (ICJ), 'meaningful negotiations' closely relate to 'negotiations in good faith' and negotiating member states should not take any actions so as to frustrate negotiations. ${ }^{38}$ Interestingly, the very same concept of 'meaningful negotiations' was introduced in WTO jurisprudence with respect to environment-related trade measures as one of the conditions to ensure application of the US sea-turtle protection policy in good faith. ${ }^{39}$ However, neither 'meaningful negotiations', nor negotiations in good faith require the states to reach an agreement, if this is not possible. It entails an obligation to negotiate, but not to conclude an agreement.

\subsection{Right and Obligation to Unilateral and Extraterritorial Action}

It has been suggested that the common concern goes beyond international cooperation and can be seen as a basis for actions erga omnes. ${ }^{40}$ In Barcelona Traction the ICJ

34 M Hoepfner, 'Behring Sea Arbitration', in R Bernhardt (ed.), Encyclopedia of Public International Law (North-Holland Publishing 1981); A Pardo and CQ Christol, 'The Common Interest: Tension Between the Whole and the Parts', in R Macdonald and DD Johnston (eds), The Structure and Process of International Law (Nijhoff 1993); Cottier, Aerni, Karapinar, Matteotti, Sépibus, Shingal, above note 10.

35 Preamble to the UNFCCC emphasis added.

36 UN GA, Transforming our world: the 2030 Agenda for Sustainable Development, A/70/L.1, 25 September 2015.

37 North Sea Continental Shelf, ICJ Reports 1969, at 3.

$38 \mathrm{~K}$ Wellens, Negotiations in the Case Law of the International Court of Justice. A Functional Analysis (Routledge 2014), at 250-4.

39 Appellate Body Report, US-Shrimp, para. 166.

40 FL Kirgis, 'Standing to Challenge Human Endeavours that Could Change the Climate', (1990) 84 American Journal of International Law 525. 
noted that '[a]n essential distinction should be drawn between the obligations of a State towards the international community as a whole, and those arising vis-à-vis another State in the field of diplomatic protection. By their very nature the former are the concern of all States. In view of the importance of the rights involved, all States can claim to have a legal interest in their protection; they are obligations erga omnes' ${ }^{41}$

The UNFCCC does not call for, but does mention, unilateral measures, which can be taken to combat climate change. In so doing, the UNFCCC sets the limits through the prism of international trade and requires that such unilateral measures do not constitute a means of arbitrary or unjustifiable discrimination or a disguised restriction on international trade. ${ }^{42}$ This provision seems to suggest a potential development of the right to act unilaterally within the framework of common concern, despite an obligation to negotiate at the international level.

The above-mentioned statements refer mainly to the right to unilateral action. The obligation to act unilaterally remains more controversial. The notion has been put forward that some obligations have evolved from the common concern of climate change. First, internationally recognized environmental standards are binding for all states, but have to apply in a differentiated manner. Second, in order to meet their international commitments and obligations, states are obliged to act both at home and in international fora. ${ }^{43}$ In addition, some parallels have been drawn between the common concern of climate change and the common concern of human rights, especially in light of a new concept of the 'responsibility to protect' (R2P), ${ }^{44}$ which will be addressed below. However, there is still no clear obligation of unilateral action by states to combat climate change, and the right to unilateral action is balanced by the co-existing obligations in other areas of law, including international trade law.

\section{RELATIONSHIP TO ESTABLISHED PRINCIPLES OF INTERNATIONAL LAW}

\subsection{Common Heritage of Mankind}

In the discourse on international law, common concern is generally discussed as distinct from the doctrine of common heritage of mankind. A few suggestions to clarify the role and contents of both principles were made. ${ }^{45}$ The origins of the concept of

\footnotetext{
41 Barcelona Traction, ICJ Reports 1970, at 32.

42 Article 3(5) of the UNFCCC.

43 F Bierman, 'Common Concern of Humankind: The Emergence of a New Concept of International Environmental Law', (1996) 34 Archiv des Volkerrechts 147.

44 See K Nadakavukaren Schefer and T Cottier, 'Responsibility to Protect (R2P) and the Emerging Principle of Common Concern', (2012) NCCR Trade Regulation Working Paper No. 2012/29.

45 J Brunnée, 'Common Areas, Common Heritage and Common Concern', in D Bodansky, J Brunnée and E Hey (eds), The Oxford Handbook of International Environmental Law (Oxford University Press 2007), at 550-73; W Stocker, Das Prinzip des Common Heritage of Mankind als Ausdruck des Staatengemeinschaftsinteresses im Völkerrecht (Schulthess 1993); R Wolfrum, 'The Principle of Common Heritage of Mankind' (1983) 43 Zeitschrift für ausländisches
} 
common heritage of mankind date back to the 1950s. The common heritage of mankind was further developed to a large extent through the application of the trust doctrine, where all resources of 'common heritage' were deemed as trust property, both within and outside the national boundaries. ${ }^{46}$ With the crystallization of its scope, the concept was included in the wording of a number of international agreements-the Moon Agreement, ${ }^{47}$ the United Nations Convention on the Law of the Sea (UNCLOS), ${ }^{48}$ and the Antarctic Treaty. ${ }^{49}$ In light of the context of use of the principle of 'common heritage of mankind', it has often been argued that it refers to the access to and exploitation of natural resources, rather than their preservation or conservation. ${ }^{50}$ As Cottier and Matteotti suggest, '[c]ommon heritage goes along with an interventionist or mixed economy regime as it was originally designed for the regime of the deep seabed at the UN Conference of the Law of the Sea (UNCLOS III)'. ${ }^{51}$ Looking at common heritage through this prism confirms that 'common concern' is indeed a different concept, which mainly relates to the permanent sovereignty of states and a duty to cause no transboundary environmental harm. ${ }^{52}$

Notwithstanding some crucial differences between the two concepts, as mentioned above, both terms seem to have initially been applied interchangeably to characterize climate change. However, treating climate change as a common heritage of mankind, instead of common concern, would lead to a different set of implications. ${ }^{53}$ Today, the notion of common concern prevails in the context of climate change.

\subsection{Permanent Sovereignty over Natural Resources}

The recognition of common concern with respect to climate change does not challenge the permanent sovereignty of any state, as none of the international climate change instruments proclaims the global atmosphere as a common property beyond the

öffentliches Recht und Völkerrecht 312; Biermann, above note 43; K Baslar, The Concept of Common Heritage of Mankind in International Law (Nijhoff 1998); A Kiss, 'International Trade and the Common Concern of Humankind', in BJ Richardson and K Bosselmann (eds), Environmental Justice and Market Mechanisms: Key Challenges for Environmental Law and Policy (Kluwer 1999); J Murillo, 'Common Concern of Humankind and its Implications in International Environmental Law', (2008) 5 Macquarie Journal of International and Comparative Environmental Law 133.

46 Baslar, above note 45 , at $65-8$.

47 Agreement Governing the Activities of States on the Moon and Other Celestial Bodies, 5 December 1979, 18 ILM 1434.

481982 United Nations Convention on the Law of the Sea, 10 December 1982, 21 ILM 1261 (1982).

49 There are a number of associated instruments to the Antarctic Treaty of 1969, which also belong to the so-called 'Antarctic Treaty System': 1991 Madrid Protocol and 1988 Minerals Convention.

50 Baslar, above note 45, at 68.

51 Cottier and Matteotti-Berkutova, above note 20, at 35.

52 See P Sands, Principles of International Environmental Law (Manchester University Press 1995), at 287.

53 Cottier and Matteotti-Berkutova, above note 20, at 34 . 
national sovereignty. ${ }^{54}$ However, the principle of permanent sovereignty and the collateral obligations are crucial in framing the concept of common concern.

The principle of state sovereignty over natural resources was formed during the process of decolonization of states. The right to self-determination led to an enhanced understanding of state sovereignty, including sovereignty over natural resources. It has mainly been invoked to balance the relationship between foreign companies exploiting natural resources and host states with abundant natural resources. ${ }^{55}$ This development of international law was reflected in UN General Assembly Resolution 1803 (XVII), which confirmed that the "right of peoples and nations to permanent sovereignty over their natural wealth and resources must be exercised in the interest of their national development and of the well-being of the people of the State concerned'. ${ }^{56}$

While the sovereignty of states applied only to natural resources within their territory, the expansion of the concept of territory itself, which started in the 1950s with a legal definition of the Continental Shelf and the Exclusive Economic Zone (EEZ), led to even more jurisdictional overlaps of several states. ${ }^{57}$ The principle of permanent sovereignty with respect to those 'new' zones was explicitly codified at the international level in the Continental Shelf Convention and consequently in UNCLOS. ${ }^{58}$ The coastal states, based on their sovereignty and jurisdiction, were vested with the right to exploit resources, but also with the obligation to manage them.

At the same time, the limits to the permanent sovereignty over natural resources crystallized in the form of an obligation not to cause significant transboundary environmental harm. ${ }^{59}$ This obligation, as a part of customary international law, also applies with respect to climate change. The ICJ confirmed that the general obligation of states to abstain from damaging the environment of other states also extends to the areas beyond national control. ${ }^{60}$ Under the rules of state responsibility, states bear the responsibility when they engage in unlawful activities (from the international law perspective) and cause damage to another state, and there exists a causal link between

54 Cottier and Matteotti-Berkutova, above note 20, at 38.

55 FX Perrez, "The Relationship between "Permanent Sovereignty" and the obligation not to cause transboundary environmental damage', (1996) 26 Environmental Law 1190.

56 The Resolution 1803 (XVII) further recognizes that infringement of national sovereignty over natural resources is contrary to the spirit and principles of the Charter of the United Nations and hinders development of international cooperation and the maintenance of peace. This resolution is considered to reflect customary international law, see Texaco Overseas Petroleum Co./California Asiatic Oil Co. v Libyan Arab Republic, 17 ILM 1 (1978).

57 See T Cottier, Equitable Principles of Maritime Boundary Delimitation: The Quest for Distributive Justice in International Law (Cambridge University Press 2015).

58 Convention on the Continental Shelf (1958), 499 UNTS 311; 1982 United Nations Convention on the Law of the Sea (UNCLOS), 10 December 1982, 21 ILM 1261 (1982).

59 The obligation of not causing significant transboundary environmental damage constitutes a part of customary international law, see e.g. Principle 21 of the Stockholm Declaration, Principle 2 of the Rio Declaration; UN GA Resolution 1515 (XV) confirms that 'the sovereign right of every State to dispose of its wealth and its natural resources should be respected in conformity with rights and duties of States under international law'; UN GA 3281 (XXIX), Charter of Economic Rights and Duties.

60 Advisory Opinion on the Legality of the Threat or Use of Nuclear Weapons, ICJ Reports (1996), at 225. 
the act or omission of the state and the damage caused. ${ }^{61}$ Similar to the Corfu Channel case, ${ }^{62}$ it could be argued that states failing to comply with specific commitments to reduce GHG emissions, adopted within the climate change regime, are committing an internationally wrongful act under customary international law. The approach is different from violating specific treaty obligations and arises in the absence of participation in a treaty system. At this stage, and given the absence of customary law in the field beyond the no-harm principles, the proposition is difficult to make, given the remoteness (both in distance and time) of the progressive effects of climate change and the difficulty of demonstrating the causal link even from a scientific point of view (with the possible exception of the rising sea levels). However, the general principles of state responsibility remain useful in a broader framework of liability and damage compensation for climate change and a more thorough analysis of the state responsibility in erga omnes situations might be of particular interest for a future study. ${ }^{63}$

\subsection{Equity}

Common concern is closely associated with equity. Equity as a principle of international law embodying fairness, impartiality and justice, ${ }^{64}$ plays an important role in understanding the concept of common concern. It has been suggested that equity and distributional justice should be the key building blocks of a global public goods framework for international cooperation. While cooperation is possible on the basis of self-interest, both equity and justice help to promote cooperation and achieve greater legitimacy and sustainability for global public goods. Equity may also entail an equitable duty to negotiate. ${ }^{65}$ It has also been proposed, in this context, to differentiate between two types of equity - horizontal (the equal treatment of equals) and vertical (a progressive distribution of burdens, e.g. financial burdens). In addition, global equity itself can be understood as a global public good. ${ }^{66}$

The principle of equity lies at the heart of protection of the climate system. The UNFCCC envisages, that ' $[\mathrm{t}]$ he Parties should protect the climate system for the benefit of present and future generations of humankind, on the basis of equity and in

61 See Article 2 of the ILC Draft Articles on Responsibility of States for Internationally Wrongful Acts and the respective commentary. Available at: http://legal.un.org/ilc/texts/ instruments/english/commentaries/9_6_2001.pdf accessed 9 August 2016.

62 Corfu Channel, Merits, Judgment, ICJ Reports 1949, p. 4, at 22-3.

63 Article 48 of the ILC Draft Articles. See note 61 above. See also: R Verheyen, Climate Change Damage and International Law: Prevention Duties and States Responsibility (Nijhoff 2005), at 240-1; P Cullet, 'Liability and Redress for Human-Induced Regime', (2007) 26A/43A(1) Stanford Environmental Law Journal and Stanford Journal of International Law, 99, at 117; M Haritz, An Inconvenient Deliberation. The Precautionary Principle's Contribution to the Uncertainties Surrounding Climate Change Liability (Kluwer 2011), at 163-6; C Voigt, 'State Responsibility for Climate Change Damage', (2008) 77 (1/2) Nordic Journal of International Law 1.

64 On the evolution and status of equity in international law see 'Introduction: Equity Revisited', in T Cottier, Equitable Principles of Maritime Boundary Delimitation: The Quest for Distributive Justice in International Law (Cambridge University Press 2015), at 1-41.

65 In the context of maritime boundary delimitation see: Cottier, above note 64, at 645-89.

66 Kaul, Grunberg, Stern, above note 8, at 70. 
accordance with their common but differentiated responsibilities and respective capabilities' ${ }^{67}$ Thus, the principle of common but differentiated responsibilities can be seen to some extent as an emanation or evolution of the traditional principle of equity, developed by public international law.

\subsection{Common but Differentiated Responsibilities}

Climate change as a common concern reflects the idea of common responsibility of states. The common responsibility, however, can be equitably differentiated, based on historical contributions of different states to climate change that depend on their respective levels of economic and social development. A differentiated approach was recognized early on in the process of the establishment of the international climate change regime. According to Principle 7 of the Rio Declaration 'States have common but differentiated responsibilities. The developed countries acknowledge the responsibility that they bear in the international pursuit of sustainable development in view of the pressures their societies place on the global environment and of the technologies and financial resources they command' ${ }^{68}$ This principle was further reflected in the $\mathrm{UNFCCC}^{69}$ and later on was implemented through the Kyoto Protocol, according to which only the so-called Annex I countries, i.e. developed countries, undertook commitments to reduce GHG emissions.

The commonality of responsibilities not only reflects the common nature of the concern at issue, but also stems from a well-established customary law obligation of states towards all other states not to cause transboundary environmental damage through activities within their own jurisdiction. ${ }^{70}$ Further, there is an obvious shift in understanding of 'transboundary harm', specifically that resulting from distant effects of atmosphere pollution, where the proximity of countries no longer plays a crucial role and the obligation goes beyond the traditional sic utere tuo ut alienum non laedas. It can be suggested that in the future the obligation of every state not to cause transboundary harm should potentially include a trusteeship obligation erga omnes, and the corresponding obligation of all other states to support the state in fulfilling its trusteeship tasks. ${ }^{71}$

67 Article 3(1) of the UNFCCC.

68 Rio Declaration on Environment and Development, UN Conference on Environment and Development, UN Doc. A/CONF.151/5 Rev (1992), 31 ILM 874.

69 Article 3(1) of the UNFCCC.

70 D French, 'Developing States and International Environmental Law: The Importance of Differentiated Responsibilities', (2000) 49(1) International and Comparative Law Quarterly 35. Already back in 1912 Oppenheim noted that '[a] State, in spite of its territorial supremacy, is not allowed to alter the natural conditions of its own territory to the disadvantage of the natural conditions of the territory of a neighbouring State', see: LF Oppenheim, International Law. A Treatise, Volume I. Peace, 2nd edition, The Project Gutenberg EBook of International Law (2012). Available at: http://www.gutenberg.org/files/41046/41046-h/41046-h.htm\#Page_182 accessed 28 July 2016). See e.g. Advisory Opinion on the Legality of the Threat or Use of Nuclear Weapons, ICJ Reports 1996, at 225.

71 H Hohmann, Precautionary Legal Duties and Principles of Modern International Environmental Law (Springer 1994), at 311-12. 
The differentiation of responsibilities makes it possible both politically and economically for all states to participate in the framework and for each state to make its contribution to the common obligation. ${ }^{72}$ It can also be seen as an emanation of equity and justice, and more specifically of historical (past) and generational (future) equity. However, with respect to the future-oriented equity, levels of differentiation will become less significant. Currently such differentiation is inadequately reflected in the UNFCCC framework. In this light, the graduation approach, based on the levels of competitiveness of countries, might be a more suitable way to implement differentiation of responsibilities in future. ${ }^{73}$ In the meantime, the common concern itself can be used to determine the scope of rights and responsibilities, including unilateral measures, of states with respect to climate change abatement.

\subsection{Responsibility to Protect}

The international community reacts gradually to the changing environment and seems to recognize that states are under an international obligation to protect and preserve their own 'internal' environment. The international community has also widely accepted a common responsibility for addressing global environmental issues. However, as noted above, it is not clear to what extent the extraterritorial unilateral reaction constitutes an obligation with respect to environmental protection. In relation to other common concerns, namely fundamental human rights, the principle of responsibility to protect (R2P) is emerging at a somewhat faster pace. It goes beyond traditional approaches to jurisdiction based on the principles of territoriality and nationality and calls for intervention against the most severe violations of fundamental human rights extraterritorially. These developments, albeit highly controversial, may exert a longterm effect on climate change policies too. The common concern of climate change will potentially include such responsibilities that go beyond national borders. ${ }^{74}$

$\mathrm{R} 2 \mathrm{P}$ arose from the common concern of massive violations of human rights, when entire populations were under threat of severe harm, and such harm could be prevented by the intervention of another state or group of states. ${ }^{75}$ It is not clear to what extent the $\mathrm{R} 2 \mathrm{P}$ includes only the right to react, or includes also an obligation to undertake unilateral action. The latter still finds little, if any, support in public international law.

72 See: P Sands, 'International Law in the Field of Sustainable Development', (1994) LXV British Yearbook of International Law 344; French, above note 70.

73 Cottier, Aerni, Karapinar, Matteotti, de Sépibus, Shingal, above note 10. See extensively on various dimensions of the common but differentiated responsibilities: CD Stone, 'Common but Differentiated Responsibilities in International Law', (2004) 98 American Journal of International Law 276. On the concept of graduation see: T Cottier, 'From Progressive Liberalization to Progressive Regulation', (2006) 9 Journal of International Economic Law 779.

74 See Krista Nadakavukaren Schefer and Pablo Arnaiz, Chapter 3, and Cottier above note 4, also in: P Hilpold (ed.), The Responsibility to Protect (R2P): A New Paradigm of International Law? (Nijhoff 2015), at 123-42.

75 The R2P was for the first time reflected in the African Union's Constitutive Act. At least with respect to the four core violations of human rights, that also constitute a part of jus cogens: genocide, war crimes, ethnic cleansing and crimes against humanity, the R2P was confirmed by the UN Security Council on several occasions. 
Most scholars still adhere to the view that R2P has to be authorized by the UN Security Council and cannot be used unilaterally, avoiding all slippery slopes back to the concepts of just war. This viewpoint may change over time under the auspices of common concern. R2P may evolve both as an obligation to act jointly and to act unilaterally in case of failure to do so with a view to protect fundamental human rights that are at risk, subject to safeguards of necessity and proportionality.

\section{COMMON CONCERN OF CLIMATE CHANGE, TRADE POLICY AND WTO LAW}

The mere existence of common concerns in different fields and the frequent failure to deal with them effectively and promptly, demonstrates that contemporary international law built upon the notions of sovereignty and territoriality of single nation states is not fully equipped to cope with the challenges of the new era. Collective action problems and free-riding often make a multilateral track more rocky and lengthy and states resort to unilateral measures, including trade measures instead. The WTO provides a legal framework which defines the scope and limits of unilateral measures that can be taken by its members. Entailing both negative and positive integration, i.e. setting limits and obliging countries to legislate (for example, in the fields of trade remedies or intellectual property), the framework also defines the scope and limits of unilateral responses to climate change-related common concerns. The question of legitimacy dealing with such unilateral measures does not exist to the extent climate and environmental policies take recourse to trade measures addressed in WTO law. The issue of legitimacy arises, however, in assessing whether or not the existing rules are sufficient for properly and effectively addressing climate change. The question also arises whether in case existing trade rules provide inadequate solutions, these rules may have to step back in unilateral pursuits of common concern relating to climate change or other major challenges. In a previous paper, the WTO was assumed to establish the basis and limits of climate change-related unilateral action. ${ }^{76}$ This chapter, and the book as a whole, takes a step further and asks whether WTO law is sufficiently responsive to the needs of combating climate change, and supporting mitigation and adaption measures. The topic entails a host of issues discussed in the volume. They essentially cover all the regulatory fields: goods, services, intellectual property (IP) and related matters of investment protection. We argue that the interpretation and application of rules, and the negotiation of new disciplines, should be informed by what we have expounded as an emerging principle of common concern.

\subsection{Climate Change and the WTO}

Climate change, like most of the other common concerns, has not been part of the core business of the WTO. The role of the WTO has been to strike a balance between trade liberalization and other legitimate interests of its members. So far, discussions within

\footnotetext{
76 Cottier, Aerni, Karapinar, Matteotti, de Sépibus, Shingal, above note 10.
} 
the WTO on climate change-related issues have been similar to the more general discussion on the relationship between multilateral environmental agreements (MEAs) and WTO law. However, climate change is drawing increasing attention owing to its potentially vast implications for international trade. ${ }^{77}$ Around 10 per cent of all MEAs contain provisions on trade measures used to achieve the set environmental goals. They either control (prohibit) trade that is seen as a source of environmental harm, or they restrict trade in certain goods with non-parties to a specific MEA (e.g. Montreal Protocol). ${ }^{78}$ The UNFCCC contains only a very general reference to international trade, namely indicating that measures (both multilateral and unilateral) used to abate climate change should not constitute a means of arbitrary or unjustifiable discrimination or a disguised restriction on international trade. ${ }^{79}$ Neither the UNFCCC, nor the Kyoto Protocol refer to specific trade measures that can, should or should not be utilized to combat climate change. In practice, states employ a range of trade measures that can be used to mitigate and adapt to climate change. They either relate to promotion of trade in 'clean technologies' or aim to restrict trade in 'grey technologies and goods'. In this respect the WTO offers two tracks to its members: (i) a multilateral track, subject to negotiations among all WTO members on specific climate change-related trade measures; (ii) a unilateral track, where a member can employ certain climate changerelated trade measures on its own, subject to multilateral dispute settlement based upon the existing international trade law framework.

\subsection{The Avenues for Trade Negotiations}

WTO members can retain, limit or expand domestic policy space with respect to climate change-related trade measures within the ongoing negotiations. The current Doha Development Agenda, initiated in 2001, focuses among other issues on clarification of the relationship between the WTO rules and MEAs, liberalization of trade in environmental goods and services (EGS), subsidies reform (especially important for the energy sector), as well as on issues pertaining to the Agreement on Agriculture, all of which may have significant implications for climate change and global warming. ${ }^{80}$ Outside the Doha Agenda, negotiations on services are relevant for climate change, in particular those addressing related services, such as engineering. In July 2014, 14 WTO members launched plurilateral negotiations on an Environmental Goods Agreement. An important achievement of this endeavour is that the current participants make up 86 per cent of global trade in environmental goods and the talks are generally open to any WTO member. China has also expressed its interest in joining the negotiations. The current talks are based on the so-called Asia-Pacific Economic Cooperation (APEC) list of environmental goods, containing some 54 items. They aim at elimination of tariffs or customs duties as the first step, and then go on to address non-tariff barriers and trade

77 M Sell, 'Climate Change and Energy', in: A Najam, M Halle, R Melendez-Ortiz, Trade and Environment. A Resource Handbook (ICTSD 2007), at 59; UNEP/WTO, above note 3, at 64.

78 UNEP/IISD, Environment and Trade: A Handbook, Chapter 5. Available at: http:// www.iisd.org/pdf/2005/envirotrade_handbook_2005.pdf accessed 9 August 2016.

79 See Article 3(5) of the UNFCCC.

80 Sell, above note 77 , at $60-1$. 


\section{Research handbook on climate change and trade law}

in environmental services at a later stage. ${ }^{81}$ This plurilateral agreement is expected to make a major contribution towards addressing climate change-related concerns in the WTO and possibly to serve as an impetus for the Doha Round. At the same time, it will address only part of the whole range of trade measures that can potentially be applied by WTO members, e.g. to prevent trade in goods produced in a GHG emission intensive manner. An additional avenue potentially available at the multilateral level within the WTO would be to adopt a Ministerial Declaration on Trade and Climate Change, similar to the Doha Declaration on the WTO Agreement on Trade-Related Aspects of Intellectual Property Rights (TRIPS Agreement) and Public Health, which would give legitimation to a more coherent interpretation of the covered agreements taking into consideration climate change as a common concern, comparable to the consideration given to human rights. ${ }^{82}$ This would not mean that the WTO would suddenly take over the tasks of an international climate surveillance authority and rule on compliance of countries with their obligations to reduce GHG emissions. On the contrary, WTO will preserve its present tasks, but will be able to balance trade liberalization interests and climate change-related concerns more coherently.

Given the state of play of the Doha Development Agenda, future initiatives inside and outside the WTO are likely to focus on specific sectors. Sectorial negotiations are likely to combine all the pertinent aspects with respect to trade in goods, services, intellectual property and investment. ${ }^{83} \mathrm{~A}$ prime topic is energy and international trade in electricity in particular. ${ }^{84}$ Other efforts may focus on technology transfer, which is essential to balance increasing recourse to non-product-related processes and production methods (PPMs), as discussed below. Non-product-related PPMs will increasingly apply to the production of highly polluting capital goods (such as steel and cement) or polluting services emitting high levels of carbon dioxide $\left(\mathrm{CO}_{2}\right)$ (such as road, maritime or air transportation), and may be linked to increased levels of tariff protection for goods or denial of market access if PPMs requirements are not met. ${ }^{85}$ Unilateral imposition of non-product-related PPMs ensuring clean production and use of clean technology requires new and imaginative approaches to transfer of technology. These efforts may be spearheaded in preferential trade agreements, both bilateral and multilateral, in particular in developing regulatory convergence over time. They may eventually be multilateralized in the WTO, extending benefits to all its members

81 Azevedo welcomes launch of plurilateral environmental goods negotiations, WTO: 2014 News Items, 8 July 2014. Available at: http://www.wto.org/english/news_e/news14_e/envir_ 08jul14_e.htm accessed 28 July 2016.

82 On a coherent approach to interpretation of the WTO in light of human rights concerns, see: G Marceau, 'WTO Dispute Settlement and Human Rights', (2002) 13(4) European Journal of International Law 753.

83 See T Cottier, 'The Common Law of International Trade and the Future of the WTO', (2015) 18 Journal of International Economic Law 3.

84 See T Cottier, 'Renewable Energy and WTO Law: More Policy Space or Enhanced Disciplines?', (2014) 2 Renewable Energy Law and Policy 40.

85 See T Cottier, O Nartova and A Shingal, 'The Potential of Tariff Policy of Climate Change Mitigation: Legal and Economic Analysis', (2014) 48 Journal of World Trade 1007. 
alike. ${ }^{86}$ Other areas, in particular agricultural subsidies or those related to oil and gas inherently need to be addressed multilaterally in order to avoid free-riding and massive market distortions.

\subsection{Avenues for Unilateral Measures: Finding Answers From Within}

In light of the collective action problem of climate change abatement, unilateral trade measures are becoming an important tool for addressing climate change-related externality. Unilateral measures per se are not prohibited in the WTO, just because they are unilateral. ${ }^{87}$ The WTO allows for regulatory diversity, as long as unilateral measures are in line with the WTO disciplines. ${ }^{88}$

A more recent practice of climate change-related unilateral trade measures demonstrates that they can influence not only the domestic behaviour of countries, but also serve as an impetus for multilateral negotiations in other fora. The most vivid example is the extension of the EU emission trading scheme to all civil air traffic to and from the European Union (EU). Indeed, although this measure remains very controversial from the WTO law perspective, ${ }^{89}$ it resulted in respective negotiations in the International Civil Aviation Organization (ICAO). ${ }^{90}$

In this chapter we would like to refer to three examples, all of which will be extensively dealt with in other contributions to this volume:91 climate change-related PPMs, application of general exceptions to justify unilateral climate change-related trade measures, and finally, the use of standards to deal with climate change concerns. All these areas are currently evolving and legal developments are mainly influenced by reports of WTO panels and the Appellate Body. While the case law does not explicitly address PPMs, it does define the scope and limits of unilateral recourse to such measures. We submit that recourse to the principle of common concern of climate change will assist in clarifying the law.

86 F Abbott, 'Innovation and Technology Transfer to Address Climate Change: Lessons from the Global Debate on Intellectual Property and Public Health', (2009) ICTSD Global Platform on Climate Change, Trade Policies and Sustainable Energy Issue Paper no. 24.

87 PC Mavroidis, GA Bermann, M Wu, The Law of the World Trade Organization (WTO). Documents, Cases and Analysis (2010), at 689-90. See also: Appellate Body Report, US-Shrimp, para. 212, and Appellate Body Report, US-Shrimp (Article 21.5-Malaysia), paras 137-8, suggesting that a complete exclusion of the unilateral measures from the scope of Article XX GATT would render the whole discipline of general exceptions inutile.

${ }_{88} \mathrm{M}$ Jansen and $\mathrm{P}$ Low, 'Dealing with Internal Measures in the Multilateral Trading System: Why, How and With What Consequences?', MIMEO. Available at: http:// citeseerx.ist.psu.edu/viewdoc/download?doi=10.1.1.572.354\&rep=rep1\&type=pdf accessed 9 August 2016; R Howse, 'From Politics to Technocracy-and Back Again: The Fate of the Multilateral Trade Regime', (2002) 96 American Journal of International Law 94.

89 Notably, the extraterritorial nature of the measure was justified by the European Court of Justice (ECJ), see: ECJ Case C-366/10, Air Transport Association of America and others $v$ Secretary of State for Energy and Climate Change, [2011] ECR I-1133.

90 See e.g. ICAO Programme of Action on International Aviation and Climate Change. Available at: http://www.icao.int/environmental-protection/Pages/programme-of-action.aspx accessed 28 July 2016.

91 See Chapters 4, 7 and 14 in this book. 


\subsubsection{Climate change-related criteria as a PPM element}

One of the most important policies that can be employed unilaterally by a WTO member is to differentiate between products according to their 'climate friendliness', and to apply differentiated tax rates, require certification or labelling of products, provide subsidies or simply only allow imports of climate-friendly products. Generally, there are three possible situations in which WTO law deals with climate change-related criteria. First, the differentiation between goods can be based on the product itself, with respect to its 'climate-friendly' qualities (e.g. energy efficiency). Second, states can apply measures to certain products depending on the inputs used in the process of producing them. Third, the measure can address the process or production method itself. This, however, has no effect on the physical characteristics of the final product (e.g. the production process which results in less GHG emissions). The third option is often referred to as non-product-related process and production methods (npr-PPMs) and is quite problematic under WTO law. ${ }^{92}$

Conventional wisdom in the WTO excludes climate change-related npr-PPMs within General Agreement on Tariffs and Trade (GATT) principles. They cannot be dealt with under the main disciplines, in particular non-discrimination or prohibition of quantitative restrictions. However, they are in principle justifiable under Article XX GATT if they pass the two-step test, i.e. fall under a specific paragraph and comply with the requirements of the chapeau. ${ }^{93}$ The majority view remains that non-trade concerns can best be dealt with under Article XX GATT..$^{94}$ This is also confirmed by the recent case law. ${ }^{95}$ This may be read as a preference for multilateral solutions to climate change as opposed to unilateral ones. ${ }^{96}$ However, it is also argued that npr-PPMs affecting the competitive relationship of the products in question can be taken into consideration for the 'likeness analysis'.$^{97}$ Depending on the specific modalities of the case, it is possible to reach the conclusion that differentiating between two products based on the climate-friendliness of their production is in line with WTO obligations. Based on the recent WTO jurisprudence on subsidies under the Agreement on Subsidies and Countervailing Measures (ASCM), it was furthermore suggested that the differentiation between 'climate-friendly' and 'climate-unfriendly' production processes might inform

92 P Low, G Marceau, J Reinaud, 'The Interface between the Trade and Climate Change Regimes: Scoping the Issues', WTO Economic Research and Statistic Division, (2011) Staff Working Paper ERSD-2011-1; C Conrad, Process and Production Methods (PPMs) in WTO Law: Interfacing Trade and Social Goals (Cambridge University Press 2011), at 469-84; K Holzer, Carbon-related Border Adjustment and WTO Law (Edward Elgar 2014), at 92-3. See also Erich Vranes, Chapter 4.

93 DC Crosby, 'Tilting at Conventional WTO Wisdom', in: T Cottier, O Nartova and SZ Bigdeli (eds), International Trade Regulation and the Mitigation of Climate Change (Cambridge University Press 2009), at 81.

94 See e.g. P van den Bossche, N Schrijver, G Faber, Unilateral Measures Addressing Non-Trade Concerns (The Ministry of Foreign Affairs of The Netherlands 2007); Sell, above note 7 , at $105-10$.

95 Appellate Body Report, EC-Seals, para. 5.90.

96 S Charnovitz, "The Law of Environmental "PPMs" in the WTO: Debunking the Myth of Illegality', (2002) 27 Yale Journal of International Law 59, at 63.

97 Low, Marceau, Reinaud, above note 92; Appellate Body Report, EC-Asbestos, paras 117-18. 
the 'likeness' analysis in the GATT, namely where it has an impact on the competitive relationship of the resulting products. ${ }^{98}$

One of the key issues raised in respect to various non-trade concerns in the WTO, and one that is also of key importance for climate change, is the role of the regulatory purpose and regulatory effects. Within the GATT framework, regulatory purposes have traditionally been shifted to the premises of the general exceptions since the aims and effect doctrine was formally discarded. Although the Appellate Body in Dominican Republic-Cigarettes suggested that ' $[\mathrm{t}]$ he existence of a detrimental effect on a given imported product resulting from a measure does not necessarily imply that this measure accords less favourable treatment to imports if the detrimental effect is explained by factors or circumstances unrelated to the foreign origin of the product, such as the market share of the importer in this case'. 99

A somewhat different approach was chosen by WTO adjudicating bodies with respect to the role of a regulatory purpose within the framework of the Agreement on Technical Barriers to Trade (TBT Agreement), dealing with technical regulations, standards and conformity assessment procedures. The recent jurisprudence suggests that the regulatory purpose plays a crucial role in the analysis of the less favourable treatment within the non-discrimination disciplines in Article 2.1 TBT Agreement, if read in conjunction with the sixth recital of the preamble to the TBT Agreement. Namely, it was suggested that the mere existence of a detrimental effect of the measure is not sufficient to demonstrate less favourable treatment of imported goods. In such cases, the panel would have to further assess whether such a detrimental impact stems exclusively from a legitimate regulatory distinction between domestic and imported products. ${ }^{100}$ This different approach can be explained primarily by the fact, that Article XX GATT does not apply to the TBT Agreement, and Article 2.2 TBT Agreement, which has similar wording to Article XX GATT, does not contain a justification clause, but instead includes a positive obligation for the WTO members. The inclusion of an additional element in the less favourable treatment analysis is aimed to make up for the absence of general exceptions clause in the TBT Agreement. ${ }^{101}$ Thus, the compatibility of climate change-related measures under the TBT Agreement would to a large extent depend on their implementation and their detrimental impact on imported like-products.

98 I Espa, K Holzer, T Payosova, Promoting Green Electricity through Differentiated Electricity Tax Schemes, in: T Cottier and I Espa (eds) International Trade in Sustainable Electricity: Regulatory Challenges in International Economic Law (forthcoming Cambridge University Press 2017).

99 Appellate Body Report, Dominican Republic-Cigarettes, para. 96; see also extensively on the proposal for an enhanced role of the regulatory purpose within the GATT framework: DH Regan, 'How to Think about PPMs (and Climate Change)', in: T Cottier, O Nartova and SZ Bigdeli (eds), International Trade Regulation and the Mitigation of Climate Change (Cambridge University Press 2009), at 91-123.

100 Appellate Body Report, US-Clove Cigarettes, paras 182, 215; Appellate Body Report, US-Tuna II, paras 215-16.

101 Appellate Body Report, EC-Seals, paras 5.124-5. 


\subsubsection{General exceptions under the GATT}

Article XX GATT performs an important function of balancing the international trade commitments of the WTO members, with their right to pursue other legitimate policies. Thus, even where a climate change-related trade measure would be inconsistent with GATT non-discrimination or quantitative restriction disciplines, the measure can be justified under Article XX if the conditions set therein are met. ${ }^{102}$ Article XX GATT contains an exhaustive list of legitimate policy objectives that might be pursued by WTO members. For climate change-related trade measures two clauses of Article XX GATT might be relevant: paragraph (b) addressing measures necessary to protect human, animal or plant life or health; and paragraph $(\mathrm{g})$ concerning measures relating to the conservation of exhaustible natural resources. It is generally accepted that the quality of the air and climatic conditions and of the ozone layer qualify as pertaining to non-renewable natural resources. Therefore, climate change-related measures could be potentially justified under Article XX(g) GATT. In view of the constantly deteriorating environmental conditions and recurring natural disasters that reveal the effects of climate change, claiming that climate change-related measures are adopted to protect human life and health also becomes more valid. Most recently, in EC-Seals, the panel and Appellate Body recognized the invocation of public morals under Article XX(a) GATT as justification for a unilateral ban on the importation of seal and seal-related products. ${ }^{103}$ Potentially, climate change could also be placed within the scope of paragraph (a), if it would at a certain point in time constitute an issue of public morals in a certain country. While the issue of an adequate nexus was not addressed under the necessity test, the EC-Seals ruling sets an important precedent for climate-related measures, basically disconnecting the measure from geographical links to the territory of the importing country except for the mere fact of importation of products to the country imposing a regulation.

The main safeguard remains the chapeau of Article XX GATT, avoiding arbitrary discrimination and disguised restrictions on trade and, importantly, imposing a duty to negotiate before unilateral measures can be lawfully adopted and implemented, especially where a unilateral measure reveals an extraterritorial reach. A member has to engage in 'on-going serious good faith efforts to reach a multilateral agreement' ${ }^{104}$ This in fact confirms our previous assumption that facing the collective action failure within the international climate framework itself, related unilateral trade measures could be justified if they meet the requirements mentioned above.

\subsubsection{International standards}

Another area where the common concern of climate change can potentially be allocated within the WTO framework is international product and production standards. The WTO disciplines dealing with technical regulations and standards encourage WTO members to use existing or almost completed international standards as a basis for their

102 Low, Marceau, Reinaud, above note 92.

103 Panel Report, EC-Seals, para. 7.631; Appellate Body Report, EC-Seals, paras 5.194-.201.

104 Appellate Body Report, US-Shrimp (Article 21.5-Malaysia), para. 153. 
national regulations. ${ }^{105}$ In practice, this would mean that where WTO members use relevant international standards as a basis for their climate change-related technical regulations, such national regulations would be presumed not to create unnecessary obstacles to international trade within the meaning of Article 2.2 TBT Agreement. ${ }^{106}$ In many narrow areas related to climate change, international standards will play an increasing role, for example, standards for renewable energy technologies, standards for life-cycle GHG emissions and energy efficiency. ${ }^{107}$

\subsection{The Role of Common Concern in WTO Law}

We submit that the issues discussed above can be clarified by taking recourse to the principle of common concern. Depicting climate change as a matter of common concern, requiring cooperation while also allowing for unilateral measures, assists in shaping the scope and limits of WTO law more precisely. It allows acceptance of the crucial concept of npr-PPMs beyond labelling and the treatment of products on the basis of criteria that make a difference in climate change mitigation and adaption. At the same time, it supports the case for effective incentives for transfer of technology. It helps to clarify complex problems of extraterritorial application of laws, defining both the scope of and limits on the imposition of regulations by countries importing goods and services. Recourse to both the aim and the effect of a unilateral measure will become relevant again. Measures adopted will have to be shown to address the common concern, to be effective and not to serve the purpose of providing disguised protection of domestic industries.

\section{CONCLUSIONS}

The emerging principle of common concern stands for the proposition of both international cooperation and the recognition that unilateral action may be necessary in the case of collective action failures. To the extent that trade instruments are used in unilateral policy, creating necessary carrots and sticks for the pursuit of climate change mitigation and adaption, WTO law offers a framework defining the scope and limits of such action. While it does not yet explicitly recognize climate change as a common concern of humankind, the emerging principle can inform negotiations and dispute settlement alike. In negotiations, it will assist in defining future obligations in the process of treaty-making and cooperation with other international organizations. ${ }^{108}$ There are key areas in which the law needs further development and clarification. A number of areas for sectorial negotiations were identified, particularly in trade in

\footnotetext{
105 Article 2.4 of the TBT Agreement.

106 Article 2.5 of the TBT Agreement.

107 R Howse, AL Eliason, 'Domestic and International Strategies to Address Climate Change: an Overview of the WTO Legal Issues', in: T Cottier, O Nartova and SZ Bigdeli (eds), International Trade Regulation and the Mitigation of Climate Change (Cambridge University Press 2009), at 81.

108 Arcas, above note 33, at 89.
} 
energy-related products and trade in electricity. These may initially be pursued outside the WTO and eventually multilateralized. Particular efforts need to be made to boost incentives for the transfer of technology in support of sustainable production. Consuming countries have a vital interest in bringing about clean production in production centres abroad. In the absence of results in this respect, the issue of npr-PPMs-key to climate change-will remain very controversial. Burdens will disproportionately shift to developing countries. The case law of panels and the Appellate Body, taking into account the principle of common concern, will be able to clarify issues to some extent by applying WTO law, its principles and exceptions, but cannot bring about a proper balance between PPMs and technology transfer, which will be essential to maintain and foster the long-term legitimacy of the WTO so that it can effectively meet the challenges of climate change that lie ahead. 